\title{
The BALANCE OF THE COALITION
}

\author{
Elisabetta De Giorgi
}

As summed up by Denis Verdini, coordinator of Forza Italia (FI), in an interview in La Repubblica after the constitutional congress of People of Liberty (PdL) at the end of March 2009, "It is more difficult to unite the elites than to unite the voters." considering the tensions that have characterized relations between allies in the government during the early part of the current coalition's tenure. This analysis can be extended to the entire government, which, beyond the newly formed PdL-composed of FI, the National Alliance (AN), and a small sub-group of the Christian Democrats who support northern Italian autonomy-also includes the Northern League (LN) of Umberto Bossi and some smaller parties, represented by a team of junior ministers: the Liberal Populists (a faction within the PdL), the Christian Democratic Party (DC), and the Movement for Autonomy (MpA) of the president of Sicily, Raffaele Lombardo.

When Silvio Berlusconi's fourth government was formed in May 2008 , it was very popular, but it had to deal with the aftermath of an unexpected worldwide economic crisis. This chapter will try to take stock of the events that affected both the government and its major protagonists by analyzing their decision-making processes and by looking at the relations between the different components of the governing coalition, two variables that often run parallel to one another.

It is known that the elections of 2008 resulted in a more cohesive institutional framework than that which had existed previously. In all, there are six parties in the lower house and six in the Senate (including the mixed group). The concentration of two principal parties in 
both houses is the highest in the history of the Republic: 77.9 percent in the lower house (with 218 members from the PD and 273 from the PdL) and 82.3 percent in the Senate (with 119 senators from the $\mathrm{PD}$ and 146 from the PdL). This has enabled the new government, led by Berlusconi, to reach an unprecedented level of support within the governing coalition, previously seen only under the first centrist governments led by Alcide De Gasperi (1946-1953). These numbers, however, have not ensured cohesiveness in legislative action and good relations between the allies. The image that has been delineated in the first year and a half of government is, in fact, that of an unstable coalition, one that frequently generates tensions that can be resolved only by the intervention of the prime minister and with outcomes that often favor the LN, the ally that is most difficult to manage. There are also strained relations between party leaders, in particular, between Berlusconi and Gianfranco Fini, the former secretary of the AN and the new president of the Chamber of Deputies. Friction is also evident between Berlusconi and Giulio Tremonti, the current minister of economy and finance, and between the prime minister and Lombardo on matters regarding southern Italy.

This chapter will examine the balance within the current coalition government. It will first look at the numbers that make this government, on paper at least, one of the strongest in the history of the Republic. It will then analyze the programs or "missions" that create common bonds between its component parts. The chapter will then review and evaluate the tensions and specific issues that have disrupted the majority during its first year and a half, creating bitter conflicts between the different factions of the government in their struggle for leadership.

\section{The Government in Numbers}

From the moment that the new government was seated on 8 May 2008 , and as a result of the streamlining of the coalition and the choice of the prime minister to assign duties, the ministerial team appeared to be one of most unified in recent Republican history, with 61 members in all, including ministers and junior ministers. ${ }^{2}$ There has been a dominance of the PdL in the new division of labor (with most posts going to members from FI), with the allocation of 70 percent of the executive positions-that is, 18 ministers and 25 junior ministersbeing assigned to Berlusconi's new party. To the LN went 4 ministerial and 5 junior minister posts. The Liberal Populists, Christian Democrats, and MpA received only a total of 4 junior minister posts. 
At the time of the first vote of confidence, the new majority supporting Berlusconi's government made up 57.3 percent in the lower house and 55.4 percent in the Senate, numbers that are practically identical to the previous Berlusconi government and significantly higher than those of Romano Prodi's first government in 1996 and his second in 2006, especially in the Senate. The data on both the composition of the administration and the parliamentary majority offer the image of a strong government, certain of the support of its majority and able to pursue its policy objectives without the likelihood of encountering major obstacles. Indeed, the success rate of the government in Parliament (meaning the proportion of legislative measures submitted by the prime minister for final approval by the Parliament) at the end of the first year and a half in office is 71.3 percent. $^{3}$ This gives the appearance of a strong executive, able to guide decision-making in both houses. As seen in figure 4.1, this is a greater success rate than in the previous government led by Berlusconi (67.3 percent) and also greater than that of the first and second Prodi governments (41.6 percent and 33.8 percent, respectively).

If you look at absolute numbers, the fourth Berlusconi government has approved fewer legislative provisions than all of the governments that have preceded it since 1996, with the exception of the second Prodi government. This phenomenon, however, should not be surprising because of renewed efforts to strengthen the legislative role of the executive branch and due to the promotion of a "rationalization" of reliance on Parliament, pursued not only through proposed substantive changes to the regulations of Parliament but also through different government initiatives. The current government focuses on cohesive legislative action linked to its overall objectives-an initiative that, from the standpoint of the government, focuses more on quality and less on quantity. ${ }^{4}$

In terms of strategy, it should be noted that the tools used by the government to approve the measures undertaken by the Cabinet have undoubtedly been important in determining the government's own rate of success. If it is true that during its first 18 months of activity the Cabinet, led by Berlusconi, has passed 87 legislative provisions (excluding the ratification of international treaties) and that, of these, 62 were adopted by both houses, it is also of note that 66.1 percent of these measures were established by decree. No previous government used emergency decrees in this way, defining, in such a decisive manner, the agenda of the legislative process and obtaining the final approval of its provisions so quickly. ${ }^{5}$ However, this success has not been judged positively by all parts of the majority coalition. On more than one occasion, Fini has expressed alarm and strongly criticized the collapse of 
FIGURE 4.1 Legislative actions of the government

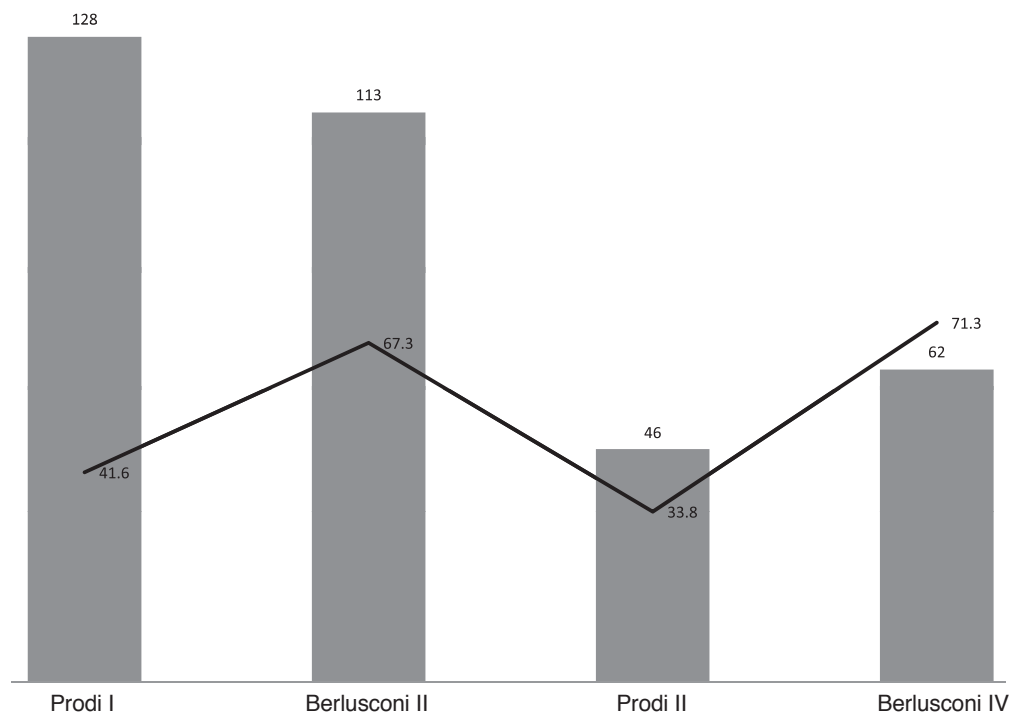

Note: Absolute number of legislative acts proposed by the Prodi I, Berlusconi II, Prodi II, and Berlusconi IV governments and approved in Parliament during the first 18 months in office (solid bar) and the percentage of total proposals made (line).

Source: http://www.governo.it.

Parliament's legislative activities, so much so that at the end of October 2009, he suspended the Chamber of Deputies for 10 days.

Of the tools that the fourth Berlusconi government has utilized to expedite the approval of its decisions, the recourse to votes of confidence must also be mentioned. In its first 18 months in office, the current government posed a vote of confidence 21 times on 14 provisions (many initiatives being the subject of requests for confidence votes in both houses of Parliament), "obliging" the assembly to approve them quickly and without reservation, given that the instrument of the confidence vote has always been for urgent decrees or major amendments submitted by the government. As has been observed, the "combined use of emergency decrees, amendments, and confidence votes confirms ... that the current government wants to 'determine' not only the timing of approval of their provisions, but also, and above all, their contents." ${ }^{6}$ This tendency is unambiguously oriented toward a "model of action that sees a strong executive backed by a solid parliamentary majority in order to adopt a rather aggressive decision-making strategy, 
choosing to focus on a limited number of priorities and thereby 'forcing' the Parliament to approve them in a very short time period."

This decision-making strategy of the current government is certainly represented in the path toward approval of the 2010 Finance Act, which was "shielded" in its move to the Chamber of Deputies by a confidence vote, thus preventing legislators from discussing it. On this occasion, President Fini did not hide his disagreement with the choice made by the government, describing it as a move that was technically "legitimate" but at the same time "despicable" because it prevented the assembly from commenting on its contents. ${ }^{8}$

All this happened and was made possible thanks to the solid majority that the government can count on, both in the Chamber of Deputies and in the Senate. However, the image of a strong executive branch, capable of determining its own agenda and controlling its parliamentary majority, clashes with the notion of a coalition government in which there are tensions between the leaders and conflicts among allies who have very different demands and priorities and are sometimes completely at odds with each other. Often, during votes, the only weapon in the prime minister's hands with the ability to calm the tension in the electorate is to promote the agenda and issues that the government has pledged to carry out, making the approval of measures stalled by either party a priority in order to avoid serious crises within the majority coalition.

\section{“The Politics of Doing"}

The fulfillment of certain specific objectives by the executive branch is an important indicator for understanding the coalition government's point of (dis)equilibrium. Let us look at the main issues around which the center-right coalition built its electoral program in 2008 and identify those goals that have been prioritized in Berlusconi's fourth government thus far.

It should be noted that the two principal allies in the government, the PdL and the LN, were not and are not bound formally by coalition policy. At the time a candidate for prime minister, Berlusconi presented an electoral platform, supported by members of the PdL, that was subdivided into "seven missions for the future of Italy." The LN proposed to share this platform with its allies, but it also advanced an autonomous proposal divided into five "resolutions." Common objectives between these two electoral manifestos were, explicitly, federalism (institutional and fiscal) and security.

Table 4.1 presents us with six of the seven missions that the PdL pledged to promote in its election campaign and related actions 
TABLE 4.1 The government program and legislative action as of 8 December 2009

\begin{tabular}{|c|c|c|c|c|c|}
\hline \multirow{2}{*}{$\begin{array}{l}\text { Mission } \\
\text { Restarting } \\
\text { Development }\end{array}$} & \multirow{2}{*}{$\begin{array}{l}\text { Areas of Action } \\
\begin{array}{l}\text { New tax regime for } \\
\text { business }\end{array}\end{array}$} & \multicolumn{2}{|c|}{$\begin{array}{c}\text { Total Commitments } \\
\text { (\% of Program) }\end{array}$} & \multicolumn{2}{|c|}{$\begin{array}{l}\text { Actions Undertaken } \\
\text { (\% of Total) }\end{array}$} \\
\hline & & 8 & $(6.8)$ & 42 & $(4.8)$ \\
\hline & Infrastructure, energy & & & & \\
\hline & resources & 9 & $(7.7)$ & 84 & $(9.7)$ \\
\hline & Employment & 5 & $(4.3)$ & 19 & $(2.2)$ \\
\hline & Liberalization & 3 & (2.6) & 7 & $(0.8)$ \\
\hline & Support for "made in & & & & \\
\hline & Italy” & 4 & $(3.4)$ & 18 & $(2.1)$ \\
\hline & Public admin. reorganization & 2 & $(1.7)$ & 107 & $(12.3)$ \\
\hline & Mission total & 31 & $(26.5)$ & 405 & $(46.6)$ \\
\hline \multirow{5}{*}{$\begin{array}{l}\text { Support } \\
\text { the Family }\end{array}$} & Lower taxes & 7 & $(6.0)$ & 21 & $(2.4)$ \\
\hline & Housing for all & 7 & $(6.0)$ & 11 & (1.3) \\
\hline & Better social services & 13 & $(11.1)$ & 10 & (1.1) \\
\hline & Future of the young & 6 & $(5.1)$ & 2 & $(0.2)$ \\
\hline & Mission total & 33 & $(28.2)$ & 46 & $(5.3)$ \\
\hline \multirow{3}{*}{$\begin{array}{l}\text { More Security, } \\
\text { More Justice }\end{array}$} & More security & 12 & $(10.3)$ & 106 & $(12.2)$ \\
\hline & More justice & 9 & $(7.7)$ & 107 & $(12.3)$ \\
\hline & Mission total & 21 & $(17.9)$ & 235 & $(27.0)$ \\
\hline \multirow{4}{*}{$\begin{array}{l}\text { Services for } \\
\text { Citizens }\end{array}$} & Health & 5 & $(4.3)$ & 3 & $(0.3)$ \\
\hline & $\begin{array}{l}\text { Schools, universities, } \\
\text { research, culture }\end{array}$ & & & & \\
\hline & $\begin{array}{l}\text { research, culture } \\
\text { Environment }\end{array}$ & $\begin{array}{r}10 \\
5\end{array}$ & $\begin{array}{l}(8.5) \\
(4.3)\end{array}$ & $\begin{array}{r}29 \\
8\end{array}$ & $\begin{array}{r}(3.3) \\
0.9)\end{array}$ \\
\hline & Mission total & 10 & $(17.0)$ & 57 & $(6.6)$ \\
\hline The South & Mission total & 8 & $(6.8)$ & 16 & $(1.8)$ \\
\hline Federalism & Mission total & 4 & (3.4) & 111 & $(12.8)$ \\
\hline Total & & 117 & (100) & 870 & (100) \\
\hline
\end{tabular}

Note: The Ministry of the Implementation of Government Programs uses the term "related actions" taken by the government to refer to every proposal connected to a specific "mission" that has been adopted.

Source: F. Marangoni, "The Only Man in Charge? The First Eight Months of Berlusconi’s Fourth Government," in Italian Politics 2008: Governing Fear, ed. G. Baldini and A. Cento Bull (New York, 2009), 117-134; Ministry of the Implementation of Government Programs, http://www.attuazione.it. 
designed to carry them out. ${ }^{9}$ As noted by Francesco Marangoni in the 2008 edition of this annual, in the first column we can see that the missions "Restarting Development" and "Support the Family" represent on paper some 55 percent of the commitments made by the future government during the vote. ${ }^{10}$

More than a year and a half after the formation of the new administration, it is particularly interesting that the actions taken by the government to fulfill these missions do not correspond at all to the given specifications. If, based on data reported by the Ministry of the Implementation of Government Programs, "Restarting Development" continues to be one of the pillars of government initiatives (accounting for 46.6 percent of total legislative action), the same cannot be said of "Support the Family," which has dropped from 28.2 percent to 5.3 percent of legislative action undertaken by the government. Particularly noteworthy is an opposite shift, which we can observe above all in the "More Security, More Justice" and "Federalism" programs. These two objectives, which are particularly important to the LN, Berlusconi's most obstinate government ally, have seen the opposite trend in their movement on the PdL's priority list. The first rose by a rate equal to 17.9 percent of actions to 27.0 percent of the total, while the second has seen a jump from 3.4 percent to 12.8 percent. At the same time, "Services for Citizens" and "The South" have registered much lower levels of initiatives undertaken by the government-from 17.0 percent to 6.6 percent and from 6.8 percent to 1.8 percent, respectively. This lack of commitment to southern Italy has aroused within the government the discontent of some allies, including Lombardo and Gianfranco Miccichè, a Sicilian who is also undersecretary of state to the prime minister.

These data show a certain imbalance in the relationship between the different components of the government coalition. While, unlike the smaller parties, the LN boasts a significant number of MPs, supporting the majority with 60 members and 26 senators, it is also true that the government's performance in its first year and a half, the priority given to certain initiatives compared to others, and the positions taken by the prime minister on certain related issues reflect a power dynamic that does not precisely correspond to party representation in Parliament.

\section{Reasons for Tension}

The asymmetric relationship between its various components has certainly created tensions within the current majority coalition. Many believe that one of the main causes of these strains has been, and 
continues to be, the unbalanced relationship established between the prime minister and Bossi. The LN has often appeared to blackmail Berlusconi's government on policy issues such as federalism, security, and immigration, and it has also engaged in political maneuvering, as in the case of the referendum on electoral reform, held on 21 June 2009.

Regarding the issue of federalism, the most significant result obtained in 2009 by the LN was the passage of Law No. 42 on socalled fiscal federalism. The Senate gave the final green light to the bill on 29 April, with 154 votes in favor, 6 against, and 87 abstentions. The Chamber of Deputies completed its review of the decision in record time, approving all articles and rejecting all amendments. To get an idea of the importance of this success, it is enough to point out that the group from the LN that was present in the Senate at the time included all of the important players, together with the party's ministers (Bossi, Roberto Calderoli, Roberto Maroni, and Luca Zaia). Wearing green ties and green scarves, they cheered and gave a standing ovation to Bossi, considered by all to be the key actor behind this reform. There was no mention of the fact that the final text of the legislation was very different from the program submitted by the PdL and the "Lombard model" proposed by the LN in their respective party platforms. However, the LN holds to the conviction that this approval is a first step toward reforms that are yet to come, trusting that the government will not say "no."

Around that same time of year, on 8 April, a conflict emerged within the majority coalition over security and immigration, another issue dear to the LN. As part of the discussion over the vote on the "security decree," the government was defeated in the Chamber of Deputies on the question of civilian patrols or ronde and on the new rules for deporting illegal immigrants. Civilian patrols, strongly desired by the LN and equally strongly criticized by the opposition, were removed by decree, only to be included in another security bill submitted to the lower house. This was a decision made by the government in response to the threat of obstructionism by the opposition groups. However, the rule specifying how long illegal immigrants can stay in short-term detention centers was nullified when the PD and the UdC put forward amendments that were approved by the lower house with the support of some members of the majority who decided to side with the opposition.

The LN, angered by the "betrayal" of the majority, demanded immediate intervention by the prime minister. In harsh words, the minister of the interior, the LN's Maroni, called for increased efforts against illegal immigration by the entire majority coalition. The following day, Berlusconi and Bossi met face to face to dispel the tension. There are many who believe that, during their discussion, the LN 
leader, in exchange for promising peace within the coalition, asked for a commitment from the prime minister to weaken the referendum on electoral reform by refusing to hold it on 7 June, which would coincide with the European and administrative elections.

Just over two weeks later, an agreement was reached in the centerright on new rules to extend the length of stay for illegal immigrants in deportation centers from two months to six months. Thus, the issues of civilian patrols and deportation centers came back to the lower house as government (i.e., LN) amendments in the so-called security bill. The security bill has 66 articles, which, in addition to reforms on civilian patrols and deportation centers, introduce extremely harsh rules against immigrants, especially against the crime of illegal immigration. The government announced a confidence vote, to take place on 12 May, on three major amendments that make up the bulk of the bill, which is divided into three sections: immigration, the Mafia, and urban safety. On 13 May, the Chamber of Deputies gave a vote of confidence to the government, thereby approving the bill, which was passed to the Senate. The same strategy-namely, that of keeping the contents of the bill closed by using a confidence vote-was adopted in the Senate. On 2 July, the security bill became law, introducing into Italy, among other things, the crime of illegal immigration, the so-called citizenship tax, and the prolongation of the stay of undocumented immigrants in detention centers for up to six months. This action has been very unpopular, and even the Vatican has been very critical of the new laws. ${ }^{11}$

On the topic of immigration, the latest confrontation within the majority coalition happened in September, when Fini, who had signed the previous Immigration Act along with Bossi (the famous Bossi-Fini law), called the denial of immigrant rights a "suicide of reason." In the days leading up to this declaration, Bossi had dismissed statements by the president of the Chamber of Deputies about the possibility of allowing immigrants the right to vote in local elections, proclaiming that "everyone is free to commit suicide as they please." From the stage of the general assembly of the UdC meeting in Chianciano, Fini took direct aim at the head of the LN: "To deny that alongside the state's obligations to immigrants there is an obligation to human rights in general is not political suicide. It is the suicide of reasonand of Christian piety." 12

Bossi did not wait to respond, nor did he limit himself to a simple comment on Fini's allegations. Instead, the LN leader warned the whole coalition: "The LN is very strong, and with its crucial votes in Parliament, its allies are constrained to follow its lead. Otherwise, we could go to early elections." ${ }^{13}$ Bossi made it clear that the LN did not want 
elections, only reforms. Stating the LN's position, his message was clear: if you do not hinder our plans for reform and do not launch proposals that we could never accept, the government will have a long life.

The imbalance in the relationship between the different components of the coalition is evident when one examines the behavior of the government on certain policy issues. However, as mentioned earlier, the LN has also managed to assert its influence within the coalition through political maneuvers. The most significant reason for this tendency of the majority to suffer the constraints applied by the LN silently and without offering too much resistance is undoubtedly the threat of a return to the polls.

Prime Minister Berlusconi, after having initially declared a certain appreciation for the issues that would come up in the referendum on electoral reform, had since come to stand against them. This has been demonstrated in actions more than in words, first, with the decision to hold the referendums with the ballot for the regional elections of 21 June. He did this rather than opting for a common election day at the start of the month, when the voters could have expressed their views all at the same time on the European Parliament, the local elections, and the three referendum questions (in the process, saving the state hundreds of millions of euros).

What are the reasons behind this choice? "The LN would have toppled the government," is what the prime minister declared on 16 April in response to the criticisms of Fini and the opposition, following the decision of the government not to incorporate the referendum vote with the European elections. ${ }^{14}$ The LN, however, did not stop at pressuring the prime minister and his coalition on the date of the referendum vote. In the aftermath of the European elections and the first round of the local elections, strengthened by a good election result, Bossi leaned on Berlusconi to boycott the referendum altogether. On 10 June, following the pact regarding the ballots and in light of the LN's confidence vote on the wiretapping law, as ordered by the prime minister, the LN asked Berlusconi to take a clear stance against the referendum. The response of the prime minister was not long in coming. "There should be direct support for the referendum on the electoral law," he said in the aftermath of a recent encounter with Bossi. ${ }^{15}$ At this point, it was Fini's response that calmed the allies. The president of the Chamber of Deputies, in fact, distanced himself from Berlusconi and the LN with a clear statement in favor of the referendum: "I am going to vote and will do so with conviction. I hope the Italians do the same." 16 The clash on this issue, according to many, served to increase the distance between Berlusconi and Bossi, on one side, and Fini, on the other. As we shall see shortly, the referendum ballot is just one of 
many reasons for the tensions that have developed over time, systematically pitting the main leaders of the coalition against each other.

The most recent confrontation between government allies arose over candidacies for the 2010 regional elections. After weeks of visible tension, on 7 November 2009, Bossi indicated that the LN would stand for the presidency of two regions in northern Italy, along with the post of vice-president of Lombardy, "left" by the outgoing governor, Robert Formigoni. The LN claimed not only the presidency of the Veneto region-which seemed inevitable, despite the bitter opposition of the outgoing governor, Gianfranco Galan, who had repeatedly threatened to run independently-but also that of the Piedmont region. The response of Ignazio La Russa, the coordinator of the PdL, in the aftermath of the statements made by Bossi, was measured but firm: "A second LN candidacy in the North is a legitimate aspiration but, at the same time, excessive." More than a month after those statements, the road to the regional elections in 2010 was still long and winding. However, even in this case, the LN was "appeased," having obtained the two candidacies in the North, in Veneto and Piedmont.

\section{The Protagonists of the Tensions}

As we have already seen, Berlusconi and Fini have long had a rather confrontational relationship. In May 2008, Fini, now president of the Chamber of Deputies, left the leadership of the AN to La Russa, the minister of defense, who became the head of the party, with the aim of concluding the path of accession to the PdL. In September, the staffs of FI and the AN created a road map for the establishment of a unified party, and by November the FI's national council approved by acclamation the merger within the PdL. Between 21 and 22 March, the last congress of the AN was held, and the party dissolved, voting for entry into the PdL. Fini recognized Berlusconi's leadership but did not hide his criticism of the risk of being "a party of a single person." Many people find the decision not to entrust the former AN leader with an official post in the new party to be at least a little strange, although this decision is partly justified by the formally non-partisan position that Fini holds as president of the lower house. To douse the fire of speculation from the stage of the congress of the PdL, however, Fini himself spoke directly to the prime minister, stating that he welcomed Berlusconi's description of the new PdL: "It is not Forza Italia squared. It is not a cold fusion between different political actors, nor is it a new election poster. Rather, it is a subject of the people, a synthesis of the experiences of women and men who come from different backgrounds, 
who are clear on the objective that government policy should be for the common good." 17 Fini did not fail to reaffirm, however, that he was still at odds with the prime minister and the LN, having different views on the role of Parliament and its institutions, especially the electoral referendum and laicità, that is, the separation of church and state.

In addition to issues related to the leadership of the party, there were many confrontations between Fini and Berlusconi in this first year and a half in office, some related to institutional issues and politics, such as the relationship between the executive branch and Parliament and the referendum election, and other issues related to policy, such as immigration, justice, and living wills. ${ }^{18}$ The first conflicts between institutions developed in October 2008, when Fini, solicited by the opposition, declared that the use of emergency decrees by the government had been excessive. Berlusconi, in response, asked him to fulfill his role and to consider, along with group leaders, how to reform the parliamentary procedure so that the process of passing laws could become more streamlined. The controversy reached a fever pitch in November with the approval of the financial package, which the government expedited with a confidence vote. This was a move that Fini called abnormal, criticizing the lack of opportunity for broad debate in the lower house.

In January, tensions rose again when the government let it be known that it wanted to use the confidence vote when drafting "anti-crisis" laws. The minister for parliamentary relations, Elio Vito, announced that the prime minister's office intended to use the confidence vote "out of respect for Parliament," given the extensive work done by the Budget and Finance Committee in the Chamber of Deputies. Fini's reaction was very harsh: "Over many years I have heard many reasons why the government might use a particular prerogative, with regard to the issue of the confidence vote, but this is the first time I've heard the confidence vote proposed by the government in honor of the work of the committee." He added: "It is also the first time that I have heard of the confidence vote being implemented in homage to the centrality of Parliament," reminding the representative of the government that the proceedings of Parliament include both "a consideration in committee and then further discussion in the assembly." 19 The prime minister dismissed Fini's findings, declaring that a confidence vote on the "anti-crisis" bill was necessary. Fini's reply was not long in coming: of course the confidence vote was indispensable, but it was "due to problems related to political debate within the majority." 20

Another inter-institutional conflict between the prime minister and the president of the Chamber of Deputies took place in March, when Berlusconi proposed a reform of parliamentary procedure in front of 
an assembly of members of the PdL. He suggested creating a system whereby only the group leaders would vote, in place of their deputies, thus streamlining the time it takes to approve laws. Fini's reaction was clear: Berlusconi's proposal would be impossible to enact. And this time, even the leaders of the PdL and the LN were skeptical of the prime minister's idea.

One of the lowest points in relations between Fini and Berlusconi occurred in September 2009, after a week of controversy over immigration policy and the case of Dino Boffo, a newspaper editor who lost his job after being harassed in one of Berlusconi's newspapers. ${ }^{21}$ On the front page of Il Giornale, the newspaper's editor, Vittorio Feltri, launched a harsh attack on Fini, calling him "shameful" and even "ridiculous" for his stances on immigration and living wills and also for his criticism of the Boffo matter. Berlusconi, who owns the paper, made no statement during the day to disassociate himself from this scandal, unlike what occurred a few hours after the Boffo story broke. The official note arrived that evening, making it known that the prime minister had no knowledge of the article on Fini and did not agree with its contents. The next day, however, the conflict rekindled itself. The prime minister announced that everything had been cleared up with Fini, but the latter immediately denied it: "Everything is not all right. Indeed, political problems remain, and it is paradoxical that Berlusconi denies this." 22 A few days after the events of Il Giornale, the battle extended to members of the PdL, with the result that Berlusconi received a letter signed by all former AN members. The letter called for a more democratic structure and a pact of continuous consultation between Berlusconi and Fini, the PDL's co-founders. It also expressed a highly critical opinion of Feltri's attack on the former AN leader. Furthermore, it called for action by the prime minister to avoid an excessive imbalance in government that favored the LN and to desist from the tendency to use intra-party problems as an excuse for bypassing discussion within the coalition. In this critical moment, the former AN members seemed to be saying that their differences were not insurmountable but could be overcome with the commitment of everyone, including the prime minister.

The most recent crisis (in chronological order) that saw Fini and Berlusconi as protagonists transpired in early December 2009, although the circumstances surrounding the conflict date from almost a month earlier. On 1 December, the newspaper La Repubblica published the transcript of a conversation that had taken place in Pescara on 6 November between Fini and the state prosecutor, Nicola Trifuoggi, during the final day of the Premio Borsellino (an event that awards a prize for social and civic commitment in memory of the murdered 
judge, Paolo Borsellino). Believing that the microphones had been turned off, Fini spoke about recent events involving Berlusconi, such as the judicial investigations concerning him and Mafioso-turnedinformant Gaspare Spatuzza's statements of regret, but also about Berlusconi's mode of thinking and how he uses the office of head of state. Fini stated: "He confuses the popular support he can count on with a sense of immunity to any other authority or check ... such as the judiciary, the Court of Auditors, the Court of Appeals, the president, and Parliament." ${ }^{23}$ The reaction from the PdL to the publication of Fini's words was harsh. Some asked Fini to clarify his statements, some wanted to kick him out of the party, and some wanted him to be dismissed from his post. The most angry of all was Berlusconi. Despite everything, however, a break was not explicitly sanctioned even on this occasion, although there are many who believe that the prime minister will not easily forget Fini's words.

Another political figure who more than once proved "inconvenient" for Berlusconi was Tremonti, the minister of economy and finance. During the first 18 months of government, the two men had many conflicts, but the most critical moment came at the end of October 2009, following the public announcement by Berlusconi of an imminent reduction of the regional business tax (IRAP). The proposal of the prime minister, which was intended to be a compromise in response to the demands of industry, was totally unexpected. Faced with a maneuver of this kind during a period of fiscal consolidation, such as the one that the country is currently going through, Tremonti threatened to leave the government immediately. Tensions were very high between Berlusconi and Tremonti for a few days, and they were mollified only through the efforts of Gianni Letta, on one side, and Bossi, on the other, who resolved the situation slowly, avoiding any permanent rupture in the party. Considering the need to reaffirm the unity of the majority coalition ahead of the 2010 regional elections, just three days after the IRAP tax cuts announcement, the prime minister was back on his feet to sign a truce with Tremonti that was strongly backed by Bossi. The LN leader has appeared increasingly linked to Tremonti, so much so that in the days immediately following the dispute, Bossi proposed Tremonti's appointment as deputy prime minister. After a difficult mediation session and a meeting in Arcore between the three principal protagonists, the controversy dissipated, and trust in Tremonti was renewed by all of the allies. However, the idea of appointing him as deputy prime minister, which annoyed many in the coalition, was thrown out.

In December, Tremonti was involved in another moment of high tension within the government, but this time Renato Brunetta, the minister of public administration and innovation, initiated the controversy. 
In an interview with the newspaper Corriere della Sera, Brunetta accused Tremonti of exercising "blind and conservative vetoes on everyone's activities" and to have practically assumed authority over the executive branch, making it very difficult for other members of the government to function. ${ }^{24}$ Despite the many signs of intolerance that had been exhibited toward Tremonti in the past, Berlusconi supported him on this occasion. The conflict subsided within a few days, despite some flare-ups due to further comments made by Brunetta, who returned to the subject after a few days, claiming to be the only true economist in the government. A ministry statement later specified that the intention was not polemical: Tremonti is, in fact, a lawyer.

In this review of the political tensions that have come to exist between the majority coalition leaders in their first year and a half of government, the story of the regional president of Sicily, MpA leader Lombardo, is certainly noteworthy. Two weeks before the European elections, Lombardo decided to reform the center-right regional government in Sicily, which was made up of the PdL, UdC, and MpA. According to the governor, the internal cohesion of the majority had dissolved, and clashes between the different components were irresolvable. These conflicts concerned the appointment of the new regional officers, health care reform, the Finance Act, and funds for depressed areas. In short, the regional government was divided on virtually all issues, and dissent on local administrative choices became apparent on the national level. The division seems to have extended to all major PdL figures in Sicily, including Renato Schifani, president of the Italian Senate, Angelino Alfano, a justice minister, and Miccichè, undersecretary of state. Consequently, Lombardo made the decision to dissolve the regional government in Sicily on 25 May. The centerright reactions were very critical. Some hypothesized that Lombardo had lost his mind, while others wanted to use the example of Sicily as a propaganda tool, in view of the European elections, where the MpA decided not to run with the PdL but with other smaller parties, including Francesco Storace's La Destra.

At the end of June, Lombardo and Berlusconi reached an agreement on the regional government in Sicily. Lombardo seemed satisfied with the end result but reiterated his firm intention to move forward in creating a party of the South, a development that Berlusconi naturally would not endorse. Tensions over the "southern question" reemerged in late July, when a group of regional members created the PdL-Sicily and announced that, after the summer, they would form an autonomous group in the Sicilian regional assembly. The question of southern Italy also came at the national level. Although they were part of the majority, members of the MpA did not participate in the final 
lower house vote on the "anti-crisis" decree and decided not to sign the PdL-LN Document for Economic and Financial Planning (DPEF) because it did not address in any way the development issues of the South. The crisis, therefore, had not been averted, and the prime minister subsequently launched a plan for the South in the Cabinet, an action that divided the PdL and created tensions between the ministers. The standoff ended on 31 July when the Inter-ministerial Committee for Economic Programming (CIPE) gave a green light to the release of 4.3 billion euros in a Fund for Underdeveloped Areas (FAS) for Sicily. Lombardo was satisfied, although the other regions of the South were perhaps less so.

Despite this, on 3 November 2009, the new PdL-Sicily, led by Miccichè, presented itself to the Sicilian regional assembly. Some members of the new group are national parliamentarians, including 15 of 34 regional deputies from the ranks of the PdL and 4 counselors from the Sicilian regional government. The initiative, welcomed by Lombardo, was naturally viewed with extreme suspicion by the national PdL coordinators, who feared a domino effect in other localities and an escalation to an organizational political crisis on the regional level. ${ }^{25}$ The last episode in the troubled history of the PdL in Sicily happened on 9 December, when Berlusconi supporters left the majority coalition under the leadership of Innocenzo Leontini. Not all of the party was called away, however. The new PdL-Sicily stayed true to Lombardo and remains part of the government, while the PD, with extreme caution, is ready to provide outside support to the governor of Sicily, who promised the formation of a new regional government by the end of 2009. The crisis of the ruling coalition at the local level, therefore, seems to have remained in place.

\section{Conclusions}

This chapter has traced the series of events that occurred during the consolidation of Berlusconi's fourth government in 2009. As we have observed, the percentages of the composition of the parliamentary majority and its supporters create the image of a solid government, sure of its parliamentary support and capable of pursuing its policy objectives without experiencing major obstacles. Indeed, looking at the success rate of the current government in Parliament after its first year and a half, the data support the perception of a strong executive, capable of directing decision-making in both houses. Furthermore, it does so more effectively than all of the preceding governments since the mid-1990s. All this was and is possible thanks to the solid majority 
on which the government can count, but it is also due to a few tools that have been overutilized, such as emergency decrees and the use of confidence votes to pass laws quickly and smoothly.

The image of an executive that can determine its own agenda and monitor its parliamentary majority has clashed, however, with that of a coalition beset by numerous tensions between its leaders and by conflicts among its allies-groups with sometimes very disparate priorities. As we have seen, often only the direct intervention of Berlusconi can heal the rifts between the allies on matters of both policy and politics. However, the prime minister himself has been a player in many intra-coalition fights, some of them very harsh.

At the end of this review of the activities of Berlusconi's fourth government and the tensions that it has passed through during the first year and a half, two fundamental problems in the equilibrium of the coalition have come to light-and they are still to be resolved. The first concerns the relationship between politics and territory and involves the coalition as a whole, especially since its main party, the PdL, does not yet seem to have found a strong footing at the local level. As we have seen, many have profited from this weakness: Lombardo's efforts to benefit the South is an important example, as is the case with the LN's political maneuverings in the North and beyond. The second problem concerns the growing question of Berlusconi's succession, which has never been publicly addressed. The matter of succession creates internal conflicts within the party leadership that are easily mitigated for now by the interventions of the prime minister but that will become increasingly difficult to contain over time. These two issues will test the coalition in the coming months. What remains to be seen is the extent to which this government, which in numbers is one of the strongest in the history of the Republic, will succeed in delaying the search for a real answer to either question.

\section{Acknowledgments}

The author would like to thank Francesco Maragoni for his invaluable assistance in assembling the data presented in this chapter and the Centro di Ricerca sul Cambiamento Politico (CIRCaP, Center for the Study of Political Change) at the University of Siena for having made material available from its own databank. 


\section{Notes}

1. F. Bei, La Repubblica, 29 March 2009.

2. A year after presenting his new Cabinet, Berlusconi then decided to increase the size of his government with the promotion of Maria Vittoria Brambilla as minister of tourism. Despite having no experience in tourism, she took office over five deputy secretaries and vice-ministers.

3. This figure does not include international ratifications.

4. The percentage of government program initiatives approved in the first year and a half of Berlusconi's fourth government is, in fact, equal to 47.1 percent of all approved initiatives versus 31.0 percent in Berlusconi's previous administration and 19.8 percent and 44.1 percent in Prodi's first and second terms, respectively.

5. The previous governments used emergency decrees much less often. In the first 18 months of Prodi's second government, the percentage of decrees out of the total number of laws passed was 54.3 percent. In Berlusconi's second term, it was 62.8 percent. In Prodi's first term it was 53.9 percent, not counting international ratifications or, in the case of the first Prodi government, reiterations of laws already in place.

6. CIRCaP, IV Rapporto sul governo italiano (Siena, 2009), http://www.gips.unisi. it/circap/.

7. Ibid.

8. G. Luzi, La Repubblica, 16 December 2009.

9. Only six of the seven government missions are indicated because the seventh, "an extraordinary plan for public finance," did not have any of its own specific objectives.

10. F. Marangoni, "The Only Man in Charge? The First Eight Months of Berlusconi's Fourth Government," in Italian Politics 2008: Governing Fear, ed. G. Baldini and A. Cento Bull (New York, 2009), 117-134.

11. For more on these subjects, please refer to the chapter by Saskia van Genugten in this volume.

12. A. Garibaldi, Corriere della Sera, 13 September 2009.

13. Ibid.

14. F. Bei, La Repubblica, 17 April 2009.

15. G. Luzi, La Repubblica, 10 June 2009.

16. Ibid.

17. “Speciale Congresso PdL,” Il Sole 24 Ore, 28 March 2009.

18. On the subjects of justice and living wills, see the chapters by Justin O. Frosini and Nicola Pasini, respectively, in this volume.

19. P. Di Caro, Corriere della Sera, 14 January 2009.

20. Ibid.

21. Boffo, the editor in chief of the daily L'Avvenire, was forced to resign after an editorial appeared on the front page of Il Giornale on 28 August 2009, referring to his alleged conviction for sexual harassment.

22. P. Di Caro, Corriere della Sera, 9 September 2009.

23. G. Luzi, La Repubblica, 2 December 2009.

24. Interview with Brunetta, Corriere della Sera, 22 November 2009.

25. E. Lauria, La Repubblica, 3 November 2009. 